\title{
Coal Business and Local Political Dynamics
}

\author{
Andi Tenri Sompa \\ Ilmu Pemerintahan FISIP Unversitas Lambung Mangkurat, Banjarmasin
}

Keywords: coal, decentralisation, local politics, mining

\begin{abstract}
Coal is not just economic goods, but also political "stuff". As economic goods, coal is one form of natural wealth of Indonesia which became the object of business because it has a high selling value. In a number of areas in Kalimantan and Sumatra, investment activities are based on natural resources, in general coal. This study attempts to answer three questions. Firstly, is the regional authority in mining business licensing consistent in formal procedures or are there also informal procedures? Secondly, whose interests are primary in coal-based investment activities in Tanah Bumbu? Thirdly, how is the involvement of coal mine operators in the political process, especially the 2005 and 2010 elections in Tanah Bumbu District following the implications in the context of local power?
\end{abstract}

\section{INTRODUCTION}

As an economic good, coal has its own political values and implications. Business and investment in coal are related to political practices, especially at the local political level (As'ad, 2015). Beginning with permission from clearance for exploration and exploitation to marketing results, there are the interests of local political elites (and bureaucratic officials) which cannot be separated in coal business and investment. In various districts/municipalities in South Kalimantan, for example, where there is a booming coal business, it is clear that there is a strong political dimension in it (As'ad, 2015).

The interests of the local political elite (and related bureaucracy officials) in the coal business are in line with the level and scope of regional authority in natural resource management (Dinas Pertambangan dan Energi Kalsel, 2011). In UU No. 4 of 2009 on Mineral and Coal Mining, regional (provincial and district/city) positions in natural resource management (minerals and coal) are important and strategic, ranging from local regulation, business licenses, guidance, settlement conflicts, inventories, research, exploration, geological information management, resource potential information, development and empowerment of local communities, delivery of inventory information, guidance, supervision of post-mining land reclamation, and others (Dinas Pertambangan dan Energi Kalsel, 2011).

The wide scope of authority allows for regions (local political elites and related bureaucratic officials) to do many things both for the benefit of regional progress and other interests. For potential areas of natural resources, such as Tanah Bumbu District, South Kalimantan, local governments are eager to encourage investment activities in the coal mining sector as a substantial natural resource in the district. In Tanah Bumbu District, most of the investment activities are based on the coal industry. Conditions in early 2011, for example, showed that more than $90 \%$ of investment activities were in the coal sector with the company amounted to about 176 pieces, while in 2007-2008 only around 46 Mining Business Licenses (IUP) for coal were granted.

Coal-based investment activities are basically required to drive the economy and earn revenue in order to build the region and create people's welfare. But, is this always, in fact, policy? There is an indication of the exchange of interests - between political elites and businessman - concerning investment activities in the coal sector in Tanah Bumbu. These indications look from the process of licensing to marketing results.

In the seasons of the election of regional heads, it is clear that there is a certain proximity between political actors (regional head candidates) and coal mining businessmen. The closeness is certainly not 
something just plain, but implies a special relationship which, in turn, has broad implications (Sung and Richter, 2007).

This study attempts to answer three questions. Firstly, is the regional authority in mining business licensing consistent in the formal procedures or are there also informal procedures? Secondly, whose interests are primary in coal-based investment activities in Tanah Bumbu? Thirdly, how does the involvement of coal mine operators in the political process, especially the 2005 and 2010 elections in Tanah Bumbu District, follow the implications in the context of local power?

This research aims to understand the power relations that occur between the political elite and coal mining businessmen in the local political sphere of Tanah Bumbu Regency. This research is placed within the local political sphere and touches on political economy.

\section{DECENTRALIZATION AND LOCAL POLITICS}

In political studies, decentralisation refers to the distribution of power based on territory. Decentralisation is concerned with the extent to which power and authority are handed over through a geographical hierarchy within the state and also with respect to the institutions and processes that permit such divisions (Balmas et al., 2014).

Smith mentioned at least 6 (six) promises of decentralisation in the context of development. According to Smith, the state mobilises support for development plans. Popular energy needs to be utilised for economic tasks or regeneration (Whitford, 2007). Plans and goals must be delivered in difficult physical and cultural conditions. Local institutions can provide local data, interpretations of local needs, indoctrination (into benefits of health programs, for example), inputs (such as savings and direct labour), and community self-help projects. Profits can be derived from what is believed to be a willingness to pay locally greater than the central tax.

Local governments allow the maximum use of local resources that have efficiency value quite apart from other benefits, such as political education, which may be brought to the community. Therefore, it is very closely related to democratic decentralisation and development that seeks to utilise the capacity to help oneself with the aim of improving the economic and social welfare of the "community" (Patnaik, 2013).

In the meantime, local politics at its baseline cannot explain and photograph problems within the scope of the administration of local government and legal-formal relationships between government institutions, but more so than that concerning the dynamics of politics, social and economic factors in the local sphere which suggest the occurrence of seizure interests, intergroup competition, conflict, behaviour of actors, and others (Boulding and Gibson, 2009).

\section{RATIONAL CHOICE}

The rational choice theory, sometimes called the public choice theory, explains the close relationship between public choice and public goods (Lehtinen and Kuorikoski, 2007). This theory focuses on the individual who makes the choice, the choice and the behaviour of the maximization that he does. The individual's decision or choice affects the public, though the public itself understands that they are not the select actors (Schotter, 2006).

Buchanan examines how to organise society to be able to enlarge opportunities freely, both in the context of the economy (market) and in the political (state) context. According to Buchanan, the political system is judged desirable to the extent that it facilitates voluntary exchange and proportionate relations between private costs and public provided (but privately) benefits (Whitford, 2007).

This theory departs from the assumption of utility maximisation. It is understood that the pillars of society are individuals, rational actors who always act to achieve their own interests. Taking advantage of the concept borrowed from microeconomic discipline, the theorists of this theory are going to explain what is often called the micro foundation of politics (Edlin, Gelman, and Kaplan, 2007).

\section{RESEARCH FINDINGS}

\subsection{Playing on Mine Licensing}

Mine clearance does have a clear procedure, but often the procedure is only a formal way to go. In practice, the informal procedure is more decisive. Lobbying is usually done by investors, and it is part of its informal procedures. Not infrequently, 
informal procedures have their own strength in the issuance of permits to control mining land to investors. As stated and experienced by Kustono, there are a number of companies whose licensing application documents are incomplete but who suddenly already have land and run mining activities. Engineering always seems to exist. They mine firstly take care of the permit then because there is already a signature or recommendation of the regent. In Tanah Bumbu, many officials, including police officials, are involved in the coal mining business.

\subsection{Elite and Mine Businessmen Interests}

On the one hand, of course, the contribution of the coal mining business in the development of Tanah Bumbu Regency cannot be denied. On the other hand, there are many complaints from various circles where there are less positive implications of business and the mining industry. The prosperity and welfare of the people are not improving greatly even though the exploitation of natural resources (coal and oresbesi) continues to be done and contributes a lot to the Original Revenue.

This is basically related to the concession and impact of the coal mining industry for improving the welfare of local communities. In reality, more concessions are given to businessmen. In terms of business concessions, the authorities will also try to accommodate the various business concessions of the businessmen. The Susanto study in South Kalimantan Province, for example, shows the granting of concessions from local authorities to businessmen who can be inventoried in the form of: [a] awarding of development projects, which can be done through appointment - even without a tender; [b] granting mining authorisation to businessmen; [c] provision of border area provisions between Banjar Regency and Tanah Bumbu Regency; [d] issuance of appointment letters in procurement and construction; [e] provision of concessions to the process of transporting coal mining products; and [f] compensation for the cost of the Barito river dredging.

The role of the state or government is also reduced (simplification) from protecting the interests of the whole society to just keep the interests of businessmen. The task is both simple and vulgar. This is exactly what is imagined in the minimal market concept. The powers they hold are merely used to serve the businessmen, and beat other groups in society who disagree.

According to Sarman, Haji Kalam - in the context of the mining business in Tanah Bumbu District - has emerged as a strongman. But he is a powerful man who is likely to be created or deliberately created by someone who is actually stronger and might be in Jakarta. Thus, Haji Kalam is a strong man created by a stronger person to secure his business interests in Tanah Bumbu District and also in South Kalimantan. That way, Haji Kalam could be a puppet or an accomplice of another stronger person.

Presumably, such a reality occurs in Tanah Bumbu Regency that can be categorised by Studwell as demonstrating the relationship between money and power. The money is owned and controlled by tycoons called godfathers, while power is in the hands of formal leaders. According to Studwell, the godfather is a peculiar elite, an economic aristocracy of outsiders who cooperate half-heartedly with the local elite. Culturally, the godfathers are chameleons who tend to be well-educated, cosmopolitan, speak more than one language and are completely isolated from the boring attention of people who are considered to be their relatives.

Under such circumstances it always happens what Acemoglu and Robinson as extractive political institutions (extractive political institutions) and extractive economic institutions (extractive economic institutions). A power that actually has roots and traditions in the past, now repeats itself with the same perpetrator. On a different side emerge inclusive political institutions and inclusive economic institutions. Political institutions and extractive economics are within the framework of vicious circles, while inclusive political and economic institutions are placed within the framework of virtuous circles.

\subsection{Coal Businessman and Elections}

Every coal miner in Tanah Bumbu Regency, especially those with a large business, does not want their business disturbed let alone stagnating and experiencing congestion. Thus, they deem it necessary to establish close and friendly relations with local political leaders. The reason, many things they can do in the context of business if close and friendly with political rulers, should be so. Thus, there is a symbiotic mutualism between the two forces. 
This happened in the case of elections in several districts in South Kalimantan in 2005. The results of the Indonesian Institute of Science study say, explicitly, in the form of explicit/explicit indeed there is no alliance between employers and authorities. Of course, this can be a form of strong alliance because they have a double position, namely as a ruler as well as a businessman. With the establishment of an alliance between rulers and businessmen, the expectation of businessmen will be that they will be able to participate in local government projects listed in the APBD. Some of the occurrences of alliance can be demonstrated by several causes, partly because of the electoral process in which the role of businessmen is very large in supporting certain candidates.

Businessmen who provide support for the election process will certainly collect project promises in the post-election period. Therefore, it can be argued that the main mode of businessmen in politics is to influence the policies of local governments that will side with the interests of the businessman in gaining access to the implementation of local government projects.

In order to influence local government policy, businessmen also formulate "shadow cabinets" and place their people to occupy certain positions. With people who have close relationships (with partners) with employers occupying the cabinet seat area, they can do "escort projects". In this case, the businessman escorts the superior project through his "hands" in the legislature - the executive, who is allied with the employers' partners. Some businessmen do not engage in direct contact with the head of the region who are important actors outside the formal structure of government, or through the regional secretary.

Large businessmen are usually directly related to the candidate, while middle-level businessmen and small businessmen, in addition to dealing with successful teams are also associated with undercover or disguised teams. Usually disguised teams come from families, are younger siblings or children of businessmen commonly referred to as "ring one", or because the candidate is an incumbent, then the one ring is the heads of service, the echelon one, and the two echelons.

\section{CONCLUSION}

The regional authority in licensing coal mining, in addition to making it easier for investors to secure their business and investment activities, also has its own implications in the context of local politics. On the one hand, local governments need investments and financial resources as a force in mobilising regional development; on the other hand, mine businesspeople need land and local government support to grow businesses and scale businesses. Business licenses issued by the local government, on the one hand, provide economic benefits for the region and increase regional income; on the other hand, they become "goods" that have a political meaning of their own. In Tanah Bumbu District, the coal mining business license becomes a political business field involving the political elite and related bureaucratic officials.

Coal mining investment activity in Tanah Bumbu Regency is quite large and produces a lot of income for the region but it does not have many implications for the improvement of people's prosperity. The high income of the region from mining business results does not go hand in hand with efforts to improve the welfare of the community. Physical development looks more as if it prioritises local government rather than accelerating community empowerment. The interests of businessmen as well as the financial benefits of the political elite and bureaucratic officials seem more advanced. Thus, investment activities in the coal sector are more prominent as the arena of interest and profit for local businessmen and elites than the interests of development and regional progress.

Another political dimension of the coal business in Tanah Bumbu is evident in the political event of the Regional Head Elections. In the 2005 and 2010 elections, for example, a number of mining businessmen provided support to certain candidates, not only moral and mass support but also financial assistance for the various needs of candidates in the electoral process. The interests of mining businessmen in the elections are not limited to the candidates who support the winning candidate, but also later business interests of the businessmen still occur after the candidate has been elected as regional head. Policies are formulated and enforced by elected regional heads. Therefore, every candidate who wins an election is never separated from the support and involvement of coal mining businessmen.

The support provided by mining businessmen to regional head candidates in the pilkada is certainly not free. They expect a reward, and when elected, the reward will be given in the form of facilities in the development of the coal mining business as required by the mine itself. Thus, the cooperation and relationship between regional leaders and coal 
mine businessmen not only lasts during the political process (pilkada) but also in later periods; in fact, in later times, the closeness is far more important than ever. That is why many of the local leaders' policies in the coal mining sector in Tanah Bumbu Regency are heavily influenced by and follow the will of coal mine businessmen.

Departing from these conclusions, this study recommends three things. Firstly, the issuance of coal mining permits should only follow official procedures in accordance with the provisions of the regulation. This is not only to strengthen the institutionalisation of the business licensing system, but also to avoid unhealthy practices in investment activity as well as to prevent the occurrence of environmental damage. Secondly, coal mining investment activities still have a main commitment to increase local revenue in order to move the local economy, to achieve regional progress, and accelerate the creation of welfare for the people of the region. Thirdly, the political participation of businessmen (coal mines) in the political process, especially the pilkada is certainly permissible and legitimate, but the assistance provided by the heads of local chief candidates should be institutionalised and follow election regulations and the rules of the General Elections Commission. This is to make the elections fair, and the elected candidates need not have a moral and political obligation to mine businessmen.
Decentralised Local Governments of India.' Journal of South Asian Development 8(1): 27-60.

Schotter, Andrew. 2006. "Strong and Wrong: The Use of Rational Choice Theory in Experimental Economics." Journal of Theoretical Politics 18(4): 498-511.

Sung, Hung En, and Linda Richter. 2007. "Rational Choice and Environmental Deterrence in the Retention of Mandated Drug Abuse Treatment Clients." International Journal of Offender Therapy and Comparative Criminology 51(6): 686-702.

Whitford, Andrew B. 2007. "Decentralized Policy Implementation." Political Research Quarterly 60(1): $17-30$

\section{REFERENCES}

Balmas, Meital, Gideon Rahat, Tamir Sheafer, and Shaul R. Shenhav. 2014. "Two Routes to Personalized Politics: Centralized and Decentralized Personalization." Party Politics 20(1): 37-51.

Boulding, Carew E., and Clark C. Gibson. 2009. "Supporters or Challengers?: The Effects of Nongovernmental Organizations on Local Politics in Bolivia." Comparative Political Studies 42(4): 479-500.

Dinas Pertambangan dan Energi Kalsel. 2011. Resume Tentang Royalty Dan Perkiraan Alokasi DBH SDA Pertambangan Umum Tahun Anggaran 2011. Banjarmasin.

Edlin, Aaron, Andrew Gelman, and Noah Kaplan. 2007. "Voting as a Rational Choice: Why and How People Vote to Improve the Well-Being of Others." Rationality and Society 19(3): 293-314.

Lehtinen, Aki, and Jaakko Kuorikoski. 2007. "Unrealistic Assumptions in Rational Choice Theory." Philosophy of the Social Sciences 37(2): 115-38.

Patnaik, Pratyusna. 2013. "Does Political Representation Ensure Empowerment? Scheduled Tribes in 